\title{
The Effect of Crowdfunding Methods and Processes on Entrepreneurship Freedom of Innovation and Value of Creation: A Study in Business Incubators in Jordan
}

\author{
Hanadi Salameh*, and Enad Quandah \\ Al-Ahliyya Amman University \\ Amman, Jordan \\ *Corresponding author's email h.salameh [AT] ammanu.edu.jo
}

\begin{abstract}
This research investigates the effect of crowdfunding on entrepreneurship. The population of the study includes Jordanian entrepreneurs, (200) questionnaires were distributed among 200 Jordanian entrepreneurs; the (200) questionnaires were all collected. The researcher used the quantitative research methods in the form of simple liner regression and multi regression. The study confirms that there is a positive impact of crowdfunding on entrepreneurship in general as well as entrepreneurs' freedom of innovation and value of creation. In addition, it was realized that out of the four investigated crowdfunding methods: reward, pre-purchasing, donation, equity and lending, the pre-purchasing method has the most positive influence on entrepreneurship freedom of innovation and value of creation. On the other hand, reward, equity, and lending did not contribute any significant effect on entrepreneurship's value of creation and freedom of innovation compared to the latter two. Furthermore, both crowdfunding processes of all-or-nothing and keep-it-all have significant effect on entrepreneurship with the latter process having a more significant effect than the former. This study confirmed the positive effect of crowdfunding methods and processes on Jordanian entrepreneurship in term of value of creation and freedom of innovation.
\end{abstract}

Keywords- Crowdfunding, Entrepreneurship, Freedom of Innovation, Startup Business

\section{INTRODUCTION}

The global financial crisis in 2008 had a big impact on the banking sector as banks and financial institutions have become more conservative and less willing to lend and fund. This has caused a big impact on worldwide economics as banks are not flexible in terms of funding and lending money to support creative ideas, startup and small and mediumsized enterprises (SMEs); hence, SMEs and entrepreneurs are in desperate need for alternative fundraising ideas after the reduction of spending in response to the financial difficulties. Therefore, crowdfunding has emerged to support entrepreneurs need for funds; increasingly so with the help of online payment and fundraising (Meyskens \& Bird, 2015). Crowdfunding allows entrepreneurs to fund their project by pooling individual and supporter contributions on a crowdfunding platform via the Internet.

Crowdfunding is preferred by entrepreneurs who are seeking to earn a competitive as it gives them the freedom of innovation, unlike other ways of funding like angels and VC (venture capital) (Macht \& Weatherston, 2014) in which business owners are involved in the process of decision making, which can be of a concern to entrepreneurs due to the high likelihood of investors interfering with their entrepreneur idea or business. In crowdfunding, the crowd is not expected to have an active role in supporting and controlling the funded business or idea (Kuti \& Madarász, 2014). Crowdfunding backers and investors are often motivated by the purpose and value creation goals of the entrepreneur, social, economic, and environmental values (Meyskens \& Bird, 2015).

Entrepreneur projects and entrepreneurs are always faced with the challenge of finding the funding they need to kick off their creative ideas and projects. Crowdfunding allows entrepreneurs to fund their project by pooling individual and backer's (a backer is an individual who contributes towards a crow fund) contributions on a crowd funding platform via the Internet. Having that said, crowdfunding platforms offer various types of process and method models that might have an impact on entrepreneurship freedom of innovation and value creation in general and in Jordan specifically; this effect should be investigated to provide the needed guidance to entrepreneurs on the most effective crowdfunding approach to leverage. 


\section{STUDY SIGNIFICANCE AND OBJECTIVES}

The relative originality of the field of crowdfunding results in a surplus of potential research avenues, all of which require exploration and subsequent theorizing and explanation (Macht \& Weatherston, 2014). According to Meyskens \& Bird (2015), entrepreneurship faces difficulties in financing new ideas; a problem solved by crowdfunding. The contributions of the research fall into various key areas: First, the result of this research may be useful and interesting for entrepreneurs and crowdfunding backers, as it will reveal the relationship between crowdfunding methods and processes and entrepreneurship freedom of innovation and value of creation. Second, this study aims to fill some of the obvious gaps in literature according (Macht \& Weatherston, 2014), Finally, this research encourages researchers in the Middle East region to undertake further studies on the subject.

The main objective of this study is to investigate the effect of crowdfunding methods and processes on entrepreneurship in terms of freedom of invitation and value of creation.

\section{STUDY QUESTIONS, HYPOTHESES AND MODEL}

The study has one main question: What is the effect of crowdfunding on entrepreneurship?

Based on the main question, the study seeks to answer the following sub-questions:

- Question 1: do crowdfunding methods affect entrepreneurship freedom of innovation and value of creation?

- Question 2: do crowdfunding processes affect entrepreneurship freedom of innovation and value of creation?

The research will address and answer these questions by administering a questionnaire among entrepreneurs in business incubators in Jordan and statistically analyzing responses and results.

hence, the goal of this study is to test the following hypotheses:

Study Main Hypothesis

H1.0: Crowdfunding does not have an impact on entrepreneurship at ( $\alpha$ 0.05)

\section{The Effect of Crowdfunding Methods}

H2.0: There is no significant effect of crowdfunding methods on freedom of innovation of entrepreneur projects in Jordan at the level of significance $(\alpha=0.05)$.

H3.0: There is no significant effect of crowdfunding methods on value of creation of entrepreneur projects in Jordan at the level of significance $(\alpha=0.05)$.

\section{The Effect of Crowdfunding Processes}

H4.0: There is no significant effect of crowdfunding processes on freedom of innovation of entrepreneur projects in Jordan at the level of significance $(\alpha=0.05)$.

H5.0: There is no significant effect of crowdfunding processes on value of creation of entrepreneur projects in Jordan at the level of significance $(\alpha=0.05)$.

\subsection{Study Model}

The model was developed based on the research of (Kuti and Madarász (2014), (Meyskens and Bird, 2015), (Courtney, 2015) and (Figliomeni , 2015). The independent variable is "Crowdfunding" with both crowdfunding methods and processes noted as sub variables. Entrepreneurship with its two dimensions of Freedom of Innovation and Value of Creation. The model will investigate the effect of crowdfunding in general on entrepreneurship as well as the effect of crowdfunding methods and processes specifically on entrepreneurship's freedom of innovation and value of creation. 


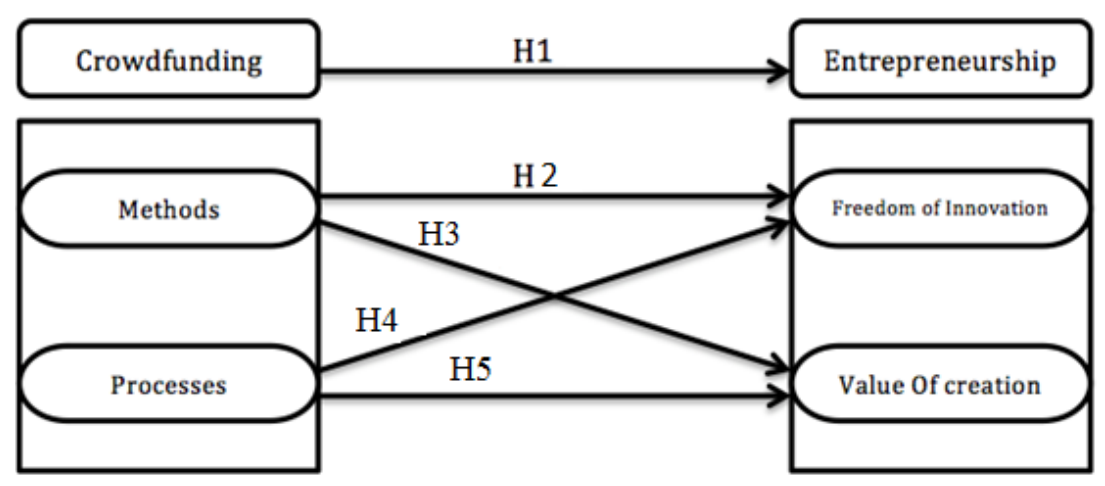

Figure (1.1): Study Model Based on (Kuti\& Madarász,2014; Meyskens\&Bird,2015; Courtney,2015; Figliomeni,2015)

\section{LITERATURE REVIEW}

\subsection{Entrepreneurship}

Entrepreneurship is an activity and a behavior that involves discovering opportunities to create new products, or production of technologies by processing the new materials (Sserwanga \& Rooks, 2013). An entrepreneur is a person who takes the risk into consideration and calls the shots of the performance of the actions. An entrepreneur also activates and manages the resources and funds of a project, while keeping in mind the possibilities of failing or succeeding (Block et al., 2015; Sserwanga \& Rooks, 2013). According to (Jurinski et al., 2016; Sørensen, 2008), entrepreneurs are divided into two types: 1 . The entrepreneurs who left his job to start his own business and 2 . The one who was forced to leave his job and decided to start his own business.

\subsection{Crowdfunding}

Crowdfunding is a method of gathering small amounts of money from a large number of people (Backers), and it has come available online since the evolution of internet technology in web 2.0 (Freedman, 2015). Crowdfunding also helps entrepreneurs and creative people with creative ideas to find support and funding to develop or improve their products or services in a significant way. Entrepreneurs can post their products or services on crowdfunding platforms (websites) and publish it to find support from Backers, not only as abstract messages but also in detail, such as video for the product in action as a prototype. The first step in the crowdfunding journey is choosing one of the crowdfunding platforms (Meyskens \& Bird, 2015). After deciding which platform to choose, an entrepreneur must create and develop their campaign in the chosen platform according to the platform regulations, methods and processes as each platform has its own methods and processes. Afterwards, the campaign owner encourages backers (crowd) to contribute funds on the same platform. At the end of funding campaign, the entrepreneur collects the raised funds in accordance with the utilized platform rules and processes. platform rules (processes). In order to have success, the campaign owner must distribute rewards. Crowdfunding platform focuses on supporting various types of creative projects such as fashion, publishing, food, art, technology, music among many other types of projects. The top funded for projects on crowdfunding platforms were in the fields of games, films/videos, design, music, and technology (Paykacheva, 2014).

Crowdfunding works through two mechanisms; the first one is "all-or-nothing" mechanism; if the project creator meets their funding goal in a dedicated period of time they will collect the money, if not they go out empty-handed (Courtney, 2015), this is the example of www.kickstart.com crowdfunding platform. The second one is "keep-what-youearn" mechanism; the project creator keeps the raised funds whether they reached the goal or not in the dedicated time (Figliomeni, 2015), for example www.Indiegogo.com crowdfunding platform implements this approach. There are various crowdfunding platforms as defined by (Meyskens \& Bird, 2015) such as StartSomeGood.com, Causes.com, Classy.com, Puddle.com, LendingClub.com, EquityNet.com, and Kiva.org. Crowdfunding platforms focus on multi-type of creative projects and business field, for instance Kickstarterer`s crowdfunding platform in 2012 supported various types of creative projects as shown in Table 2.2 (Paykacheva, 2014). 
Table (2.2): Kickstarterer`s crowdfunding platform in 2012 as defined by (Paykacheva, 2014)

\begin{tabular}{|l|l|l|l|l|}
\hline Category & Launched & Successful & Pledged & Pledgers \\
\hline Art & 3,783 & 1,837 & $\$ 10,477,939$ & 155,782 \\
\hline Comics & 1,170 & 542 & $\$ 9,242,233$ & 177,070 \\
\hline Dance & 512 & 381 & $\$ 1,773,304$ & 23,807 \\
\hline Design & 1,882 & 759 & $\$ 50,124,041$ & 536,469 \\
\hline Fashion & 1,659 & 434 & $\$ 6,317,799$ & 83,064 \\
\hline Film \&Video & 9,600 & 3,891 & $\$ 57,951,876$ & 647,361 \\
\hline Food & 1,828 & 688 & $\$ 11,117,486$ & 138,204 \\
\hline Games & 2,796 & 911 & $\$ 83,144,565$ & $1,378,143$ \\
\hline Music & 9,086 & 5,067 & $\$ 34,953,600$ & 522,441 \\
\hline Photography & 1,197 & 427 & $\$ 3,283,635$ & 46,550 \\
\hline Publishing & 5,634 & 1,666 & $\$ 15,311,251$ & 262,738 \\
\hline Technology & 831 & 312 & $\$ 29,003,932$ & 270,912 \\
\hline Theater & 1,787 & 1,194 & $\$ 7,084,968$ & 95,225 \\
\hline
\end{tabular}

\subsection{Crowdfunding Methods}

There are four types of crowdfunding methods that determine the technique of raising money via the crowdfunding online platform. These methods are: Reward based, Donation based, Equity based, and Lending based.

\subsubsection{Reward Based Crowdfunding Method}

Reward- based crowdfunding method is a mechanism in which entrepreneurs must give contributors or backers something for their fund contribution (Courtney, 2015). Reward based crowdfunding is divided into two earlier and later levels. During the earlier levels of a reward model, the entrepreneur or the campaign owner who fundraises for a specific project, give contributors symbolic-non-physical rewards such as a thank you or a nominal physical reward such as such as T-shirts, key chains or caps (De Buysere et al., 2012; Mitra, 2012). In the later level, contributors or backers will receive the product or service that the entrepreneur aims to produce since the amount of money offered from contributors covers the cost of the product or service (Kickstarter, 2016; Mitra, 2012). This type of crowdfunding is legal in Jordan according to the Electronic Transaction Act (Gov. Jordan, 2001).

\subsubsection{Donation Based Crowdfunding Method}

Donation based crowdfunding is giving without expecting a personal benefit or profit in return. Quite the opposite of the crowdfunding method, this definition works for both the perspective of entrepreneur and backer. Both the entrepreneur and backer are looking for the benefit of implementing such project or idea (Meyskens \& Bird, 2015). Mainly, the donation method works with projects that have humanitarian goals. Donation method works with non-profit organization (NGO) and providing needed support and help in a humanities catastrophe crisis (Courtney, 2015; Sheik, 2013). On the other hand, a pre-purchasing approach to differs in that backers usually contribute to the project by prepurchasing the product or service the entrepreneur project is indented to implement, deliver, or build.

\subsubsection{Equity Based Crowdfunding Method}

Equity based crowdfunding method is an old method of funding from crowds; it was based on selling securities of a company or a creative project to venture capital (VC) and Angel investors and other people through legal stock market. Nowadays, since the revolution of technology has facilitated the ability of entrepreneurs to sell securities online, the main barrier to utilize this method is the need for government legislations to utilize it online. This was forbidden in USA before 2012 until the US government initiated a law for under the name (JOBS) - The Jumpstart our Business Startups in 2012 (REISER \& DEAN, 2015; Yamen \& Bartholomew, 2015).

In order to implement this type of crowdfunding in Jordan, the government must legislate rules and laws to organize and regulate these activities online. Referring to the Jordanian Law of Electronic Transaction Act (Gov. Jordan, 2001) according to, Clause 6, Statement B, it is forbidden to sell stocks and securities, unless it is mentioned in Jordan security commission. 


\subsubsection{Lending-Based Crowdfunding Method}

Lending-based crowdfunding method is a peer-to-peer lending implemented online with contributors lending money to entrepreneurs with money being paid back by the entrepreneur with interest (Barasinska \& Schäfer, 2014). The online money lending is influenced by cultural and geographical factors (Burtch et al., 2013), as a Muslim country, Jordan follows Al-Shariaa that prohibits lending money to other people with interest as a profit, and this is in contrast with the lending goal of earning a profit (Burtch et al., 2013).

\subsection{Crowdfunding Process Models}

Crowdfunding processes are mechanisms that an entrepreneur uses when utilizing the Reward-based and the Donation-based crowdfunding methods to collect money, and they are divided into two types:

1. All or Nothing $(\mathrm{AON})$

2. Keep It All (KIA)

\subsubsection{All or Nothing $(A O N)$ :}

In this process, the entrepreneur who is applying a campaign on a platform must determine a period of time for the campaign and the amount of money needed from the crowdfunding. If the amount of money was collected in the time interval determined, then the campaign will be a success and the entrepreneur will be able to collect the money. If the determined amount of money wasn't collected in the time frame assigned, then the campaign is a failure and the entrepreneur will not get any money (Kickstarter, 2016; Figliomeni, 2014).

\subsubsection{Keep It All (KIA):}

This type of crowdfunding process allows the entrepreneur to get the amount of money collected after creating the campaign, even though the time frame of the campaign assigned is finished, whether they reached their goals or not (Cumming et al., 2015). With this approach, entrepreneurs allocate the risk to the crowd when an underfunded project goes ahead.

\subsection{Entrepreneurship Freedom of Innovation}

Freedom of innovation is a major factor in the entrepreneurship domain as it will encourage entrepreneurs to execute and implement their best ideas. Having angel investors funding entrepreneur projects might jeopardize freedom of innovation (Mitteness et al., 2012). An Angel investor is an individual person who invests their own money in the earlier stages of the production of a new product or service, in return of equity shares of the company. Angel investor in most cases have their success criteria and will try to take away the entrepreneur's right to decide the business model they see proper. On the other hand, crowdfunding guarantees freedom of innovation while entrepreneur proceed with their project implementation. For entrepreneurs, venture capital (VC) can be another alternative to fundraise their projects because of consortium of investors. But this alternative of raising money may overwhelm entrepreneurs with many venture capital requirements.

\subsection{Entrepreneurship Value of Creation}

According to (Santos, 2012), value of creation from an activity happens when the aggregation value of society's members increases after accounting for the opportunity cost of all the resources used in that activity. Entrepreneurship projects supporting education, health freedom, and environmental recycling and green energy will add value to the community hence having a high value of creation. This added value will attract backers and crowd funders support. That being said, funding from the crowd can generate very good income by selling products and generate profit to guarantee the success of the project and its continuity, hence generating great value as well. This success will lead to the growth of the project and this growth guarantee a profit for the entrepreneur and will be accompanied with creating new job opportunities (Meyskens \& Bird, 2015).

\section{STUDY SAMPLE, RESEARCH DESIGN, AND METHODS}

To achieve the study objectives, the analytical quantitative approach was used in order to gather and analyze data and test hypothesis.

\subsection{Sample}

The data was collected using a structured questionnaire distributed to entrepreneurs in business incubators in Jordan Amman. Business incubators in Amman include but not limited to (IPark, Oasis 500, Queen Rania Center of Entrepreneurs, Zain, Unmia, Orange). The study population consists of all entrepreneurs in business incubators in Jordan who are counted approximately at 400. The unit of analysis for this study is the entrepreneur. The sample size is 196 (Sekaran, 2010) at a confidence level of $95 \%$ and a margin of error of $5 \%$. The responses of a random sample of 
entrepreneurs in Jordanian incubators were investigated and analyzed; 200 questionnaires were distributed among entrepreneurs and collected completely.

\subsection{Research Design and Methods}

This study uses the analytical descriptive approach through collecting data that are related to the effect of crowdfunding on entrepreneurship from the perspective of entreprenerus in business incubators in Jordan. The study is classified as a field study to collect the primary source data. The study depends on the analytical descriptive approach to investigate the effect of crowdfunding on entrepreneurship from the perspective of entreprenerus in business incubators in Jordan. In order to test the hypothesis, the questionnaire approach was used. This questionnaire was prepared based on the relevant theoretical framework and the literature review.

The study tool is represented by a questionnaire. The first section of the questionnaire aimed at collecting demographic variables as well as knowledge of entrepreneurship of the study sample. This involves: age, gender, knowledge of or participation in entrepreneur projects, receiving funds about of enterprisers projects, and participation in crowdfunding projects. The second section focused on gathering data about the factors that driving the effect of crowdfunding on entrepreneurship, and these factors are divided into five groups: 1. Entrepreneurs and Entrepreneurship 2. freedom of innovation 3. Value of creation, 4. Crowdfunding methods and 5. Crowdfunding processes.

A (1-5) Likert Scale was. Each score is given a weight represented by a percentage as shown in table (3.2). Regarding the limits of the degree of importance for the paragraphs of the study, a statistical standard has been used to divide the levels of importance into three levels (high, medium and low).

Table (3.2): Degrees of Likret Scale

\begin{tabular}{|l|l|}
\hline Score & Weight $(\%)$ \\
\hline 1 & $0-20 \%$ \\
\hline 2 & $21-40 \%$ \\
\hline 3 & $41-60 \%$ \\
\hline 4 & $61-80 \%$ \\
\hline 5 & $81-100 \%$ \\
\hline
\end{tabular}

\subsection{Validity and Reliability}

In order to verify the quality of the questionnaire and its suitability to test the study hypotheses, validity and reliability tests were conducted. Validity refers to the fitness or relevance of the measurement while reliability refers to the consistency or stability of measurement (Sekaran, 2010).

\subsubsection{Cronbach's Alpha}

The researcher used the Cronbach alpha method for measuring the stability of the questionnaire. The rate of questionnaire reliability coefficient of 0.858 refers to the strength and stability of the questionnaire suitability for use as a tool for the study.

Table (3.4): Cronbach's alpha

\begin{tabular}{|l|l|l|l|}
\hline No & Item & No. of Items & Cronbach's Alpha \\
\hline 1 & Crowdfunding & 9 & 0.831 \\
\hline 2 & Process AON (All or Nothing) & 4 & 0.837 \\
\hline 3 & Process KIA (Keep It All) & 5 & 0.866 \\
\hline 4 & Entrepreneurship & 8 & 0.840 \\
\hline 5 & Freedom of innovation & 3 & 0.839 \\
\hline 6 & Value of creation & 5 & 0.847 \\
\hline
\end{tabular}

\subsubsection{Variance Inflation Factor VIF}

Variance Inflation Factor (VIF) test was used to verify the tolerance and multi-collinearity of the study instrument. Table (3.5) indicates that there is no multi-collinearity within the independent variables of the study. 
Table (3.5): Multi collinearity to test for main Hypothesis

\begin{tabular}{|l|l|l|l|}
\hline \multirow{2}{*}{ Model } & Collinearity Statistics \\
\cline { 3 - 4 } \cline { 3 - 4 } & Crowdfunding & 0.476 & VIF \\
\hline 2 & Process AON (All or Nothing) & 0.821 & 2.102 \\
\hline 3 & Process KIA (Keep It All) & 0.666 & 1.218 \\
\hline 4 & Entrepreneurship & 0.527 & 1.501 \\
\hline 5 & Freedom of Innovation & 0.477 & 1.899 \\
\hline 6 & Value of Creation & 0.584 & 2.098 \\
\hline
\end{tabular}

\subsubsection{The Correlation Coefficient}

The internal consistency of the questionnaire was measured via the calculation of the correlation coefficients among the questionnaire items. Correlation coefficient measures the strength and direction of a linear relationship between two variables on a scatterplot (Sekaran, 2010). Table (3.6) shows correlation coefficients among the questionnaire sections, which shows that the correlation coefficients have shown significance at a moral level of 0.05 and thus paragraphs resolution is considered as valid for what intended to measure.

Table (3.6): Correlation Coefficients.

\begin{tabular}{|l|l|l|l|l|l|l|l|}
\hline & $\begin{array}{l}\text { Entrepreneurs } \\
\text { and } \\
\text { entrepreneurship }\end{array}$ & $\begin{array}{l}\text { Freedom } \\
\text { of } \\
\text { innovation }\end{array}$ & $\begin{array}{l}\text { Value } \\
\text { of } \\
\text { creation }\end{array}$ & Crowdfunding & $\begin{array}{l}\text { AON } \\
\text { (All or } \\
\text { Nothing) }\end{array}$ & $\begin{array}{l}\text { KIA } \\
\text { It All) }\end{array}$ & $\begin{array}{l}\text { Crowdfunding } \\
\text { processes }\end{array}$ \\
\hline Crowdfunding & $.560^{* *}$ & $.628^{* *}$ & $.491^{* *}$ & 1 & $.385^{* *}$ & $.524^{* *}$ & $.580^{* *}$ \\
\hline $\begin{array}{l}\text { Process AON (All } \\
\text { or Nothing) }\end{array}$ & $.345^{* *}$ & $.297^{* *}$ & $.207^{* *}$ & $.385^{* *}$ & 1 & $.263^{* *}$ & $.738^{* *}$ \\
\hline $\begin{array}{l}\text { Process KIA } \\
\text { (Keep It All) }\end{array}$ & $.370^{* *}$ & $.463^{* *}$ & $.442^{* *}$ & $.524^{* *}$ & $.263^{* *}$ & 1 & $.845^{* *}$ \\
\hline $\begin{array}{l}\text { Entrepreneurs and } \\
\text { entrepreneurship }\end{array}$ & 1 & $.597^{* *}$ & $.548^{* *}$ & $.560^{* *}$ & $.345^{* *}$ & $.370^{* *}$ & $.450^{* *}$ \\
\hline $\begin{array}{l}\text { Freedom of } \\
\text { innovation }\end{array}$ & $.597^{* *}$ & 13 & $.553^{* *}$ & $.628^{* *}$ & $.297^{* *}$ & $.463^{* *}$ & $.489^{* *}$ \\
\hline Value of creation & $.548^{* *}$ & $.553^{* *}$ & 1 & $.491^{* *}$ & $.207^{* *}$ & $.442^{* *}$ & $.424^{* *}$ \\
\hline
\end{tabular}

** Correlation is significant at the 0.01 level (2-tailed).

\section{ANALYSIS AND RESULTS}

The statistical analysis process has been done by SPSS program through using the descriptive static tools which involved measures of central tendency as average, standard deviation, using frequency tables, percentages as well as the analytical statistical methods that required to test hypotheses by using the multiple and simple deviation analysis including t-test which is used to test the impact of each independent variable in the study model on the dependent variable. In addition to the correlation coefficient which helps in explaining the nature and relationship power among variables' impact which will be studied later. Analysis of variance is to test the existence of differences in the impact of the independent variables on the dependent variable, according to some demographic characteristics.

Table (3.3): Arithmetic mean, SD, item importance and importance level of independent and dependent variables.

\begin{tabular}{|l|l|l|l|l|}
\hline type of variables & Variables & Mean & SD & Level \\
\hline \multirow{3}{*}{ Independent Variable } & crowdfunding methods & 2.6678 & 0.646 & High \\
\cline { 2 - 5 } & crowdfunding processes & 2.458 & 0.926 & High \\
\hline \multirow{3}{*}{ Depended variable } & Freedom of innovation & 2.458 & 0.926 & High \\
\cline { 2 - 5 } & value of creation & 2.318 & 0.693 & High \\
\cline { 2 - 5 } & Entrepreneurship & 2.6477 & 0.636 & High \\
\hline
\end{tabular}




\subsection{Hypotheses Testing}

In order to test this hypothesis, simple linear regression was applied to determine whether crowdfunding had significant effect on entrepreneurship.

\section{H1 $1_{0}$ : There is no significant effect of crowdfunding on entrepreneurship in Jordan at the level of significance $(\alpha=$} 0.05).

The results are provided in table (4.6) indicating a significant effect of the predicting variable (crowdfunding) on the dependent variable (entrepreneurship). Hence, the null hypothesis was rejected and the alternative hypothesis was accepted.

Table (4.6): Model summary for the effect of crowdfunding o entrepreneurship in Jordan.

\begin{tabular}{|l|l|l|l|l|l|l|}
\hline Result & Independent Variable & $\mathrm{R}$ & $\mathrm{R} 2$ & $\mathrm{t}$ & $\mathrm{T}$ & $\mathrm{Sig}$ \\
\hline significant & Crowdfunding & \multicolumn{2}{|c|}{0.56} & 0.3 & 9.5 & \multicolumn{2}{|c|}{1.} & 0 \\
\hline
\end{tabular}

The Effect of Crowdfunding Methods on Entrepreneurship:

$\mathrm{H2}_{0}$ : There is no significant effect of crowdfunding methods on freedom of innovation of entrepreneur projects in Jordan at the level of significance $(\alpha=0.05)$.

In order to test this hypothesis, simple linear regression was applied to determine whether crowdfunding had significant effect on entrepreneurship. The results are provided in table (4.7) indicating that there is a significant effect of the predicting variable (crowdfunding methods) on the dependent variable (freedom of innovation). The null hypothesis was rejected and the alternative hypothesis was accepted confirming that there is an effect of crowdfunding methods on entrepreneurship freedom of innovation. This results aligns with the findings by (Kuti \& Madarász, 2014), (De Massis et al, 2015), and (Mollick \& Robb, 2016).

The researcher is concerned in seeking the freedom of innovation from the entrepreneur's perspective that comes from the crowd since there are many types of innovation

Table (4.7): Model summary for effect of crowdfunding methods on entrepreneurship freedom of innovation

\begin{tabular}{|l|l|r|r|r|r|r|}
\hline Result & Independent Variable & R & R2 & t & T & Sig \\
\hline Significant & crowdfunding methods & \multicolumn{2}{|c|}{0.62} & 0.3 & 11.3 & \multicolumn{2}{|c|}{1.} & 0 \\
\hline
\end{tabular}

addition, multiple regression was used to verify the effect of each of the crowdfunding method: Reward, Pre-purchasing, Donation, Equity and Lending individually on the freedom of innovation at $(\alpha \leq 0.05)$. As it is noticed in table (4.8), we observed that the crowdfunding methods (Pre-Purchasing and Donation) have significant effect on entrepreneurship freedom of innovation. On the other hand, the funding methods (Rewards, Equity and Lending) have insignificant effect on freedom of innovation. From the result of the Model summary for multiple regression (R) coefficients for crowdfunding methods the results indicate that there is inverse relationship of (Rewards) on the freedom of innovation at $(\alpha \leq 0.05)$. 
Table (4.8): Model summary for multiple regression (R) coefficients for crowdfunding methods (Reward, Prepurchasing, Donation, Equity and Lending) on the freedom of innovation at $(\alpha \leq 0.05)$.

\begin{tabular}{|l|l|l|l|l|l|l|}
\hline Result & $\begin{array}{l}\text { Independent } \\
\text { Variable }\end{array}$ & $\mathrm{R}$ & $\mathrm{R} 2$ & $\mathrm{t}$ & $\mathrm{T}$ & $\mathrm{Sig}$ \\
\hline Insignificant & Reward & $-.072-$ & $-.062-$ & $-.964-$ & 1.96 & 0.336 \\
\hline The most significant effect & $\begin{array}{l}\text { Pre- } \\
\text { purchasing }\end{array}$ & 0.455 & 0.377 & 5.983 & 1.96 & 0 \\
\hline Significant & Donation & 0.227 & 0.183 & 2.942 & 1.96 & 0.004 \\
\hline Insignificant & Equity & 0.096 & 0.09 & 1.616 & 1.96 & 0.108 \\
\hline Insignificant & Lending & 0.043 & 0.042 & 0.7 & 1.96 & 0.485 \\
\hline
\end{tabular}

\section{$\mathrm{H3}_{0}$ : There is no significant effect of crowdfunding methods on value of creation of entrepreneur projects in Jordan at the level of significance $(\alpha=0.05)$.}

In order to test this hypothesis, simple linear regression was applied to determine whether crowdfunding had significant effect on entrepreneurship. The results are provided in table (4.9) indicating a significant effect of the predicting variable (crowdfunding methods) on the dependent variable (value of creation). The null hypothesis was rejected and the alternative hypothesis was accepted. This results aligns with the findings of (De Buysere et al., 2012) in how the majority of created value and economic contribution in Europe comes from SME and entrepreneurship projects and businesses. In addition, it supports the findings of (Agafonow A 2014) on how entrepreneurship maximize not only on value capture, but also on value creation to fuel operations and growth.

Table (4.9): Model summary for effect of Crowdfunding on entrepreneurship measure of entrepreneur projects in

\begin{tabular}{|l|l|l|l|l|l|l|}
\hline Result & Independent Variable & R & R2 & t & T & Sig \\
\hline significant & crowdfunding methods & 0.491 & 0.241 & 7.940 & 1.96 & 0 \\
\hline
\end{tabular}

Jordan

In addition, multiple regression was used to give more insights on the effect of each of the crowdfunding method: Reward, Pre-purchasing, Donation, Equity and Lending individually on the value of creation at $(\alpha \leq 0.05)$. As it is noticed in table (4.10), we found that the crowdfunding methods (Pre-purchasing and Donation) have significant effect on the value of creation while the crowdfunding methods (Reward, Equity and Lending) have insignificant effect on the value of creation.

Table (4.10): Model summary for multiple regression (R) coefficients for crowdfunding methods (Reward, Prepurchasing, Donation, Equity and Lending) on the value of creation at $(\alpha \leq 0.05)$.

\begin{tabular}{|l|l|r|r|r|r|r|}
\hline Result & $\begin{array}{l}\text { Independent } \\
\text { Variable }\end{array}$ & $\mathrm{R}$ & $\mathrm{R} 2$ & $\mathrm{t}$ & $\mathrm{T}$ & $\mathrm{S}$ ig \\
\hline Insignificant & Reward & $-.140-$ & $-.091-$ & $-1.671-$ & 1.96 & 0.336 \\
\hline The most significant effect & Pre-purchasing & 0.324 & 0.201 & 3.789 & 1.96 & 0 \\
\hline Significant effect & Donation & 0.222 & 0.134 & 2.56 & 1.96 & 0.004 \\
\hline Insignificant & Equity & $-.005-$ & $-.003-$ & $-.072-$ & 1.96 & 0.108 \\
\hline Insignificant & Lending & 0.093 & 0.068 & 1.355 & 1.96 & 0.485 \\
\hline
\end{tabular}

The Effect of Crowdfunding Processes on Entrepreneurship: 
$\mathrm{H4}_{0}$ : There is no significant effect of crowdfunding processes on freedom of innovation of entrepreneur projects in Jordan at the level of significance $(\alpha=0.05)$.

In order to test this hypothesis, simple linear regression was applied to determine whether crowdfunding processes had significant effect on freedom of innovation. The results are provided in table (4.11) indicates significant effect of the predicting variable (crowdfunding processes) on the dependent variable (freedom of innovation). Hence, the null hypothesis was rejected and the alternative hypothesis was accepted which state:

$\mathrm{H5}_{0}$ : There is no significant effect of crowdfunding processes on the value of creation of entrepreneur projects in Jordan at the level of significance $(\alpha=0.05)$.

Table (4.11): Model summary for effect of Crowdfunding processes on freedom of innovation measure of entrepreneur projects in Jordan.

\begin{tabular}{|l|l|l|l|l|l|l|}
\hline Result & Independent Variable & R & R2 & t & T & Sig \\
\hline significant & Crowdfunding processes & 0.489 & 0.239 & 7.879 & 1.96 & 0 \\
\hline
\end{tabular}

In order to test this hypothesis, simple linear regression was applied to determine whether crowdfunding processes had significant effect on value of creation. The results are provided in table (4.12). The results indicate a significant effect of the predicting variable (crowdfunding processes) on the dependent variable (value of creation). The null hypothesis was rejected and the alternative hypothesis was accepted. This in turn aligns with the results and findings by( Meyskens \& Bird, 2015) and (Mollick \& Robb, 2016).

Table (4.12): Model summary for effect of Crowdfunding processes on value of creation measure of entrepreneur projects in Jordan.

\begin{tabular}{|l|l|l|l|l|l|l|}
\hline Result & Independent Variable & R & R2 & t & T & Sig \\
\hline significant & crowdfunding processes & 0.424 & 0.179 & 6.581 & 1.96 & 0 \\
\hline
\end{tabular}

\section{CONCLUSION}

Based on the data analysis and hypotheses testing provided above, here after is a summary of the results

1. There is significant effect of crowdfunding on entrepreneurship in Jordan at the level of significance $(\alpha=0.05)$.

2. There is a significant effect of crowdfunding methods on freedom of innovation as well as value of creation for entrepreneur projects in Jordan at the level of significance $(\alpha=0.05)$.

3. Taking in consideration the multiple regression coefficients for crowdfunding methods, the results indicate that both Pre-purchasing and Donation methods have significant effect on freedom of innovation and value of creation while Rewards, Equity, and Lending have an insignificant effect.

4. Considering the multiple regression coefficients for crowdfunding methods, the results indicate that there is inverse relationship of the Rewards method on the freedom of innovation and value of creation at $(\alpha \leq 0.05)$.

5. There is a significant effect of crowdfunding processes on freedom of innovation and value of creation of entrepreneur projects in Jordan at the level of significance $(\alpha=0.05)$.

Crowdfunding has been gaining momentum both in research and professionally as it has become one of the major funding sources for entrepreneurs and their projects. Due to its relatively young age in general and in Jordan specifically, this research provides an insight into the relationship and impact of crowdfunding on entrepreneurship. Specifically, in Jordan as a developing country with growing and sometimes challenged economy, talented and skilled people try to find alternative ways to fund and run their own entrepreneur's ideas and projects. In Jordan as it is everywhere, funding for these entrepreneur's projects is always a challenge and a struggle. Crowdfunding hence has become the tool and the source that can provide funding alternatives to entrepreneurs. This research aimed to study the effect of crowdfunding on entrepreneurships. It tried to determine the crowdfunding methods and processes that affect entrepreneurship in term of value of creation and freedom of innovation. The result of this study is useful and interesting for entrepreneurs and crowdfunding platforms, as it will reveal the relationship between crowdfunding methods and processes from one side and entrepreneurship freedom of innovation and value creation on the other side. 
In this study, a model to investigate the crowdfunding effect on entrepreneurship was developed. The model had two main variables crowdfunding and entrepreneurship. The construct of crowdfunding included methods and processes, while the construct of entrepreneurship included freedom of innovation and value of creation. The developed model was applied and tested in the context of Jordanian entrepreneur. For hypotheses testing, a questionnaire instrument was designed on the basis of the constructed model. The questionnaire instrument was validated in terms of clearance, meaning, format, and its ability to measure the constructs included within the research model. 200 questionnaires were distributed, collected, and statistically analyzed. The analysis conducted using Statistical Package for Social Sciences (SPSS) Version (21); data analysis, results were presented and discussed.

The study results demonstrated having a positive direct impact of crowdfunding on entrepreneurship confirming the need to invest more on enhancing fund raising mechanism and encouraging crowdfunding platforms to support entrepreneur in establishing start-up companies. Based on study results and conclusions, the following recommendations are suggested: 1 . Using crowdfunding methods by Jordanian entrepreneurs can increase their entrepreneurship freedom of innovation. 2. As donation and pre-purchasing crowdfunding methods have significant effect on Jordanian entrepreneurs' freedom of innovation and value of creation compared with rewards, equity, and lending methods, both donation and pre-purchasing methods are recommended when the freedom of innovation and value of creation are of importance to Jordanian's entrepreneurs. 3. A relevant law must be legislated in Jordan to facilitate the donation and prepurchasing crowdfunding methods online since they are the most significant methods for Jordanian entrepreneurs.

\section{REFERENCES}

[1] Agafonow, A. (2014). Toward A Positive Theory of Social Entrepreneurship. On Maximizing Versus Satisficing Value Capture. Journal of Business Ethics, 125(4), 709-713.

[2] Barasinska, N., \& Schäfer, D. (2014). Is Crowdfunding Different? Evidence on the Relation between Gender and Funding Success from a German Peer-to-Peer Lending Platform. German Economic Review, 15(4), 436452.

[3] Block, J., Sandner, P., \& Spiegel, F. (2015). How do risk attitudes differ within the group of entrepreneurs? The role of motivation and procedural utility. Journal of Small Business Management, 53(1), 183-206.

[4] Burtch, G., Ghose, A., \&Wattal, S. (2013). Cultural differences and geography as determinants of online prosocial lending. MIS Quarterly, Forthcoming, 14-021.

[5] Courtney, V. (2015). Crowdfunding brings new opportunities for CPAs. Journal of Accountancy, 220(4), 3842.

[6] Cumming, D. J., Leboeuf, G., \&Schwienbacher, A. (2015). Crowdfunding models: Keep-it-all vs. all-ornothing. All-Or-Nothing (May 31, 2015).

[7] De Buysere, K., Gajda, O., Kleverlaan, R., Marom, D., \& Klaes, M. (2012). A framework for European crowdfunding. European Crowdfunding Network (ECN), available at www.europecrowdfunding. org/european_crowdfunding_framework, 61.

[8] De Massis, A., Di Minin, A., \&Frattini, F. (2015). Family-Driven Innovation. California Management Review, 58(1), 5-19.

[9] Freedman, D. (2015). The Growth of Equity Crowdfunding. Value Examiner, 6-10.

[10] Jurinski, J. J., Down, J., \&Kolay, M. (2016). Helping Older, Encore Entrepreneurs Anticipate Financial Risks. Journal of Financial Service Professionals, 70(1), 81-90.

[11] Kuti , M., \& Madarász , G. (2015). Crowdfunding. Public Finance Quarterly, , 355-366.

[12] Macht, S., \& Weatherston, J. (2015). The Benefits of Online Crowdfunding for Fund-Seeking Business Ventures., Strategic Change, 23(1/2), 1-14.

[13] Meyskens, M., \& Bird, L. (2015). Crowdfunding and Value Creation. Entrepreneurship Research Journal, 5(2), $155-166$.

[14] Mitra, D. (2012). The role of crowdfunding in entrepreneurial finance. Delhi Business Review, $13(2), 67$.

[15] Mitteness, C., Sudek, R., \&Cardon, M. S. (2012). Angel investor characteristics that determine whether perceived passion leads to higher evaluations of funding potential. Journal of Business Venturing, 27(5), 592606.

[16] Mollick, E., \& Robb, A. (2016). Democratizing Innovation and Capital Access. California Management Review, 58(2), 72-87.

[17] Paykacheva, V. (2014). Crowdfunding as a customer engagement channel.

[18] REISER, D. B., \& DEAN, S. A. (2015). A Catalyst for Social Enterprise Crowdfunding. Indiana Law Journal, 90(3), 1091-1129.

[19] Santos, F. M. (2012). A positive theory of social entrepreneurship. Journal of Business Ethics, 111 (3), $335-$ 351. 
[20] Sekaran, U., \& Bougie, R. (2010). Research methods for business: A skill building approach (5th ed.). West Sussex, UK: John Wiley \& Sons Ltd

[21] Sheik, S. (2013). Fast Forward on Crowdfunding. The Computer \& Internet Lawyer, 30(8), 17-21

[22] Sserwanga, A., \& Rooks, G. (2013). IDENTIFYING HIGH POTENTIAL ENTREPRENEURS IN A DEVELOPING COUNTRY: A CLUSTER ANALYSIS OF UGANDAN ENTREPRENEURS. Journal of Developmental Entrepreneurship, 18(2), 1-15.

[23] Yamen, S., \& Bartholomew, A. (2015). Crowdfunding as the Latest Spin for Fraudsters in Utah. Utah Bar Journal, 28(3), 54-57.

[24] Gov. Jordan (2001). الاردن - Retrieved April 1, 2016, from http://www.wipo.int/edocs/lexdocs/laws/ar/jo/jo058ar.pdf 